\title{
Milan Hodás
}

Comenius University, Bratislava

milan.hodas@flaw.uniba.sk

\section{Attorney-client privilege (History and aim - constitutional view)}

DOI: http://dx.doi.org/10.12775/SIT.2017.030

\section{Historical introduction*}

Professional privilege is closely associated with the idea of Publilius Syrus: Fidem qui perdit, nil, potest ultra perdere ${ }^{1}$ (he who has forfeited his good faith has nothing else to lose). The possible foundation of the tradition of professional privilege can be found in the biblical Proverbs attributed to Solomon ${ }^{2}$. In verses 9 and 10 of chapter XXV, the Proverbs say, "If you take your neighbor to court, do not betray another's confidence, or the one who hears it may shame you and the charge against you will stand"3. The institution of professional privilege in case of doctors can be already found in the $5^{\text {th }}$ century BC in the form of the Hippocratic Oath, which in conclusion contains a promise of confidentiality: "Whatsoever I shall see or hear in the course of my profession, as well as outside

* This articel is result of project GAČR „Odhalováni temného koutu legislativního procesu: Příprava návrhů zákonů exekutivou”, reg. č. 17-03806S.

${ }^{1}$ K. Rebro, Latinské právnické výrazy a výroky, Bratislava 1995, p. 124.

2 A. Krsková, Otázniky nad profesijným tajomstvom, "Právny obzor" 1993, No 5, p. 445.

${ }^{3}$ P. Lambert, Profesijné tajomstvo, Brusel 1985, p. 190, [in:] Etika právnického povolania, A. Krsková, Bratislava 1994 p. 16, cited according to A. Krsková, Otázniky nad profesijným tajomstvom, p. 445. 
my profession in my intercourse with men, if it be what should not be published abroad, I will never divulge, holding such things to be holy secrets" ${ }^{4}$. The inviolability of confessional privilege was declared in the $4^{\text {th }}$ century $\mathrm{AD}$ at the ecclesiastical council in Carthage. The Council of Lateran IV (1125 AD), already declares a law in connection with this issue and for the violation of confessional privilege sets very strict punishments ${ }^{5}$ as well as later in the $15^{\text {th }}$ century, the Council of Trent confirms the confessional privilege as an absolute principle which overrules even the inquisition ${ }^{6}$.

The tradition of professional privilege in the legal profession is also very old. The privileged character of the communication between an attorney and a client was already recognized in Roman law, in which the testimony of an attorney to his client was considered inadmissible, either because the testimony, beneficial for the client, was considered partial or because an adverse testimony destroyed the reputation of the attorney and made him unreliable to trust ${ }^{7}$. Lawyer Farinacius, in his Commentaries, bases the bond of professional privilege on a simple idea of protection, which a patron offers to the client and which also includes a ban on disclosing confidential information obtained from the client or a ban on testifying against him: "Advocatus im causa in qua est causa, propter praesumptiam affectionem testimonium ferre non potest" . Cicero in his Philippicae condemns an attorney that betrayed the trust placed by a client into the defence ${ }^{9}$. However, in this period, the institution of confidentiality was rather based on

${ }^{4}$ Cited according to ibidem.

5 "A priest who reveals a sin confided to him in confession is to be deposed and relegated to a monastery for the remainder of his life (Council of Lateran IV, Canon 21)".

${ }^{6}$ A. Krsková, Prielom do profesijného tajomstva?, "Bulletin advokacie" 2007, No 7-8, p. 66.

7 M. Radin, The Privilege of Confidential Communication Between Lawyer and Client, p. 488-489, [in:] M. Cohn, The Evisceration of the Attorney-Client Privilege in the Wake of September 11, 2001, "Fordham Law Review" 2003, Vol. 71, p. 1235.

${ }^{8}$ P. Lambert, op. cit., p. 190.

${ }^{9}$ A. Krsková, Otázniky nad profesijným tajomstvom, p. 445. 
the nature of the attorney-client relationship than on the effects of this institution ${ }^{10}$. Although it is necessary to say that in the Code of Justinian from $534 \mathrm{AD}$, the role of attorneys is described with a pathetic pathos: "Attorneys who clarify [...] the problems of a case and help the person concerned to restore the law are not less useful to the citizens than a soldier, resistant to the wounds and battles, who fights for the defence of his homeland and family. We think that not only those who are armed with sword are fighting for our empire, but also the attorneys who, with well-elaborated words and arguments, are defending the hope, the life and the livelihood of their clients" ${ }^{11}$.

The institution of attorney-client privilege was already known in the Middle Ages. For instance, in medieval Germany, we can find an explicitly codified duty of confidentiality already in 1495, with attorneys authorized to appear before the Reichskammergericht ${ }^{12}$. The first accounts of attorney-client privilege in the system of common law appear during the reign of Queen Elisabeth I. (1533-1603), and in 1577 this institution is already considered to be unambiguously recognized ${ }^{13}$. Until the $18^{\text {th }}$ century, the basis for recognizing attorney-client privilege was based on the existence of an oath of honor that the attorney would hold the interests of the client. If an attorney was forced to breach this oath, this breach would besmirch his gentleman's honor ${ }^{14}$. Later, however, this rationale began to change. Under pressure to strengthen the mechanisms of the judicial process of truth-finding, this privilege has begun to erode. Individual honor of an attorney had to give way to justice. However, a new justification for this institution has emerged spontaneously - it is essential for a free and unrestricted consultation

${ }^{10}$ E. G. Thornburg, Sanctifying Secrecy: The Mythology of the Corporate Attorney-Client Privilege, “Notre Dame Law Review” 1993, Vol. 69, p. 160.

${ }^{11}$ Codex Justinianus, Kapitel de advoc.div.iud. 2.7., cited according to R. Magnus, Das Anwaltsprivileg und sein zivilprozessualer Schutz, Tübingen 2010, p. 10.

${ }^{12}$ Ibidem, p. 17.

13 M. Cohn, op. cit., p. 1235.

${ }^{14}$ Ibidem. 
of an attorney. This justification has later also become the basis for the modern institution of attorney-client privilege ${ }^{15}$.

However, we also have to stop in the history of our geographic area. The duty of confidentiality was enshrined in the second chapter of the Imperial Patent of 24 July 1852 No. 138/1852, which prescribes the Advocacy order to the Kingdom of Hungary, Croatia, Slavonia, the Banat of Temes, and Serbian Vojvodina with the exception of the military boundary - among the basic duties of an attorney was the duty to carry out his/her profession in accordance with the sworn oath while being diligent, honest and silent.

The Hungarian Law Art. XXXIV/1874 - the advocacy order, which had been applied for several decades in our territory, regulated the duty of confidentiality in $\S 49^{16}$. This institution then found its continuance in $\S 4$ of Act No. 322/1948 Coll. on the Legal Profession, according to which an attorney was obliged to advocate the duty of confidentiality of the matter entrusted to him, unless the party has discharged this obligation. However, in the important state interest, the Minister of Justice could have waived the attorney's duty of confidentiality, in which case the attorney was obliged to testify before the court or any other public authorities. The duty of confidentiality could not be invoked by an attorney either in cases which concerned criminal acts under Act No. 231/1948 Coll. on the Protection of the People's Democratic Republic, which each citizen was obliged to report to the Security Authority.

Similarly, to the previous case, also in Act No. 114/1951 Coll. on the Legal Profession, the attorney-client privilege could be breached on the basis of an exemption from that commitment given by the Minister of Justice due to the existence of an important state interest. The duty of confidentiality also did not apply in cases when a testimony of an attorney was about a criminal act which he or she was obliged to report under the threat of prosecution for failure to report this criminal act, i.e. high treason, subversion of the Republic, terror, destructive actions, sabotage, espionage, jeopardizing the safety of state secret, war damage, prohibited

15 Ibidem, p. 1236.

${ }^{16}$ P. Kerecman, Kapitoly z dejín advokácie, Košice 2005, p. 112. 
acquisition and possession of firearms, counterfeiting and fraudulent alteration of the means of payment, putting into circulation counterfeit or fraudulently altered means of payment, endangering public safety, second degree murder, robbery, theft of property in socialist ownership, harm done to property in socialist ownership, defection or rebellion.

Act No. 57/1963 Coll. of 9 July 1963 on the Legal Profession contained the institution of confidentiality in $\S 19$. An attorney could be exempted from the duty of confidentiality by the Center for Czechoslovak Advocacy based on an important state interest. The duty of confidentiality could not be invoked by an attorney either in cases when it was a statutory obligation to prevent the commission of a criminal act pursuant to Section 167 of the then applicable criminal code (i.e. criminal act of high treason, subversion of the state, terror, etc.)

According to Act No. 133/1975 Coll. on the Legal Profession, an attorney could be exempted from the duty of confidentiality by the Committee of the Center for Slovak Advocacy, if it was in the important state interest that he/she would testify about information protected by the institution of confidentiality before court, state or other authority. The duty of confidentiality could not be invoked by an attorney either in cases when it was a statutory obligation to prevent the commission of a criminal act.

As part of the social changes following the Velvet Revolution, Act No. 132/1990 Coll. on the Legal Profession already did not allow the exemption of an attorney from the duty of confidentiality, however, this institution of professional privilege did not cover cases where it was a statutory obligation to prevent the commission of a criminal act.

Act No. 586/2003 Coll. on the Legal Profession, until 2008, had been breaching the duty of confidentiality when it concerned a statutory obligation to prevent the commission of a criminal act, when it concerned a dispute between an attorney and his/her client or his/her legal successor, as well as in disciplinary proceedings pursuant to Act on the Legal Profession. On 2 July 2008, Act No. 297/2008 Coll. on Prevention of Legalization of the Proceeds of Criminal Activity and Terrorist Financing and on Amendments 
and Supplement to Certain Acts was adopted, which meant a more pronounced breach of the institution of attorney-client privilege. It was such a significant breach that it sparked controversy in the entire European Union (EU).

\section{The institution \\ of legal professional privilege - the means to achieve legitimate aims?}

From a theoretical and a legal point of view, it can be agreed that the institution of legal professional privilege of attorneys in a democratic society is related to the pursuit of legitimate democratic aims and the rule of law. As stated by Lenka Rehulová: "The duty of confidentiality of an attorney, establishing the relationship between the attorney and the client is a basic element and a prerequisite of providing legal assistance and justice at all" ${ }^{17}$. The judgment of the Constitutional Court of the Czech Republic (Constitutional Court of the CR) II. ÚS 2894/08 of 28.08.2009 also talks about the importance of the institution of attorney-client privilege: "The obligation to maintain confidentiality is the basic prerequisite for provision of legal aid and thus a necessary condition for a democratic society to function. The practice of the profession of an attorney at law is based on a confidential relationship between the attorney at law and the client, and on the trust of the client in the confidentiality of the attorney at law. The Constitutional Court has stated earlier that this is in no instance a privilege of the attorney at law which should be the basis for exemption from a generally valid and binding legal order, but it is an obligation imposed on the attorney at law in the interests of their clients and for their protection. In such a sense, professional secret and maintaining the same by the attorney at law is endowed with relevant protection, this particularly in situations when such an obligation by the attorney at law may be endangered, for example, precisely in cases such as a search of

17 L. Řehulová, Institut zproštěni povinnosti mlčenlivosti advokáta klientem, “Právní rozhledy" 2011, No 11, p. 397. 
a home of an attorney at law or their office". This section has been referred to by the Constitutional Court of the Czech Republic also in point 17 of the judgment II. ÚS 889/10 of 25.11.2010.

As an example from another field in which the confidentiality of the relationship is also protected, may include the right to protection of journalist sources, which journalists could invoke and which is based in the jurisprudence of the European Court of Human Rights (ECtHR). It is accepted that the press could not fulfill its role of "a barking dog defending democracy" if they would not cooperate with various sources, whereby for such cooperation, trust is important and could not be built without the right of the journalists to keep the source of their information secret under Article $10^{18}$ of the European Convention for the Protection of Human Rights and Fundamental Freedoms (ECHR) ${ }^{19}$. From the democratic rule of law point of view, this is also about pursuing a legitimate aim.

Another pertinent example with an illustrative potential for comparing and examining the degree of legitimacy of a breach of the institution of attorney-client privilege is Section 130, sub-section 2, second sentence in the Criminal Procedure Code No. 31/2005 Coll. as amended, according to which a witness has the right to refuse to testify if his testimony could breach confessional secrecy or the secrecy of information entrusted to him in writing or verbally under

18 "Article 10. Freedom of expression

1. Everyone has the right to freedom of expression. This right shall include freedom to hold opinions and to receive and impart information and ideas without interference by public authority and regardless of frontiers. This article shall not prevent States from requiring the licensing of broadcasting, television or cinema enterprises

2. The exercise of these freedoms, since it carries with it duties and responsibilities, may be subject to such formalities, conditions, restrictions or penalties as are prescribed by law and are necessary in a democratic society, in the interests of national security, territorial integrity or public safety, for the prevention of disorder or crime, for the protection of health or morals, for the protection of the reputation or rights of others, for preventing the disclosure of information received in confidence, or for maintaining the authority and impartiality of the judiciary".

${ }^{19}$ See also for example, J. Herczeg, $K$ právu novinářů nezveřejňovat své informačni zdroje, "Právní rozhledy" 2011, No 10, p. 343-350. 
the seal of secrecy as to a person entrusted with pastoral care. The above-mentioned examples are evidence that when respecting social interests, the democratic society knows of cases when an interest of protecting a confidential relationship prevails over the interest of the society to gain information, whether for the purposes of criminal proceedings or for the purposes of security prevention. I would particularly like to point out that as long as the society recognizes as a legitimate aim clerical reasons in the regulation of secular matters and for these reasons it protects the confessional secrecy by law, we should be very careful when approaching the issue of breach of professional privilege, which is largely justified by secular reasons - balancing out the power interventions, i.e. by the rule of law, protection of democracy and freedom of the individual. Therefore, it is necessary to sensitively search for a legitimate boundary between freedom and security. As Alexandra Krsková says: "The protection of a citizen in the rule of law is unimaginable without respecting the secrecy of his private and professional life. However, their absolute respect could, in many cases, paralyze the functioning of the social life"20.

\section{The institution of confidentiality - general legal principle of the law of the European Union}

The laws of legal professional privilege are not harmonized throughout the EU. They are governed by the national law of individual EU Member States. The treaty on the Functioning of the European Union and the Treaty on the European Union do not contain expresis verbis any provision on legal professional privilege of attorneys.

The Court of Justice of the European Union recognized EU legal professional privilege as a fundamental right in 1982, in the landmark decision $A M \& S v$ Commission of the European Communities, Case C-155/79. The Court of Justice of the EU held that legal professional privilege in European Law was necessary so that

${ }^{20}$ A. Krsková; Otázniky nad profesijným tajomstvom, p. 448. 
any person is able to consult a lawyer without constraints. Legal professional privilege is an essential corollary to the full exercise of the rights of defence also in the European Union Law ${ }^{21}$.

As the Advocate General states in her Opinion of 29 April 2010 in the case of Akzo Nobel Chemicals Ltd and Akcros Chemicals Ltd $v$ European Commission, Case C-550/07, the protection of confidentiality of communications between an attorney and his client constitutes a general legal principle in the Law of the EU, which has the legal force of primary law. This follows from the principles common to the legal systems of the Member States, as the protection of confidentiality of communications between attorneys and clients is currently recognized in all 27 Member States of the EU ${ }^{22}$. The protection of confidentiality of communication between attorneys and clients is even enshrined in constitutional law in particular in Bulgaria (Article 30 (5) of the Constitution of the Republic of Bulgaria) ${ }^{23}$ and in Spain (Article 24 (2) of the Constitution of the Kingdom of Spain) ${ }^{24}$ and is part of constitutional provisions in Italy, Portugal, Romania and Sweden ${ }^{25}$. The protection of the confidentiality of communications between attorneys and clients can also be derived from Article 7 of the Charter of Fundamental Rights of the European Union (Charter) (respect for communications) in conjunction with Articles 47 and 48 (2) of the Charter (the right to be advised, defended and represented, respect for the rights of the defence).

${ }^{21} A M \& S v$ Commission of the European Communities, Case C-155/79, point 18.

${ }^{22}$ See point 47 of the Opinion of the Advocate General Juliane Kokott from 29 April 2010 in the case Akzo Nobel Chemicals Ltd a Akcros Chemicals Ltd $v$ European Commission, C - 550/07.

${ }^{23}$ Article 30(5): "Everyone shall be entitled to meet his legal counsel in private. The confidentiality of such communication shall be inviolable".

${ }^{24}$ Article 24(2): "The law shall regulate the cases in which for reasons of family relationship or professional secrecy it shall not be obligatory to make declarations concerning allegedly criminal actions"

http://www.senado.es/constitu_i/indices/consti_ing.pdf (access: 27.07. 2011).

${ }^{25}$ See the Opinion of the Advocate General Juliane Kokott from 29 April 2010 in the case Akzo Nobel Chemicals Ltd a Akcros Chemicals Ltd v European Commission. 
The jurisprudence of the Court of Justice of the EU is significant for the legal establishment of the institution of attorney-client privilege. As stated in $\S 23$ and 24 of the Judgment of the Court of Justice of the European Communities of 18 May 1982 in the case $A M \& S v$ Commission of the European Communities, Case C-155/79, the protection of the confidentiality of written communications between attorney and client is an essential element to ensure that the rights of defence may be exercised to the full. It is based on the attorney's role as "collaborating in the administration of justice by the court", who is required to provide, in full independence, and in the overriding interests of that cause, such legal assistance as the client needs.

In point 32 of the Judgment of the Court of the EU of 26 June 2007 in the case Ordre des barreaux francophones et germanophone and others $v$ Conseil des ministers, Case C-305/05, it is stated that attorneys would be unable to carry out their task of advising, defending and representing their clients appropriately, who would in consequence be deprived of the rights conferred on them by Article 6 of the ECHR as well as Articles 47 and 48 of the Charter, if attorneys were obliged, in the context of judicial proceedings or the preparation for such proceedings, to cooperate with the authorities by passing them information obtained in the course of related legal consultations.

The secondary law of the EU has also affected the institution of confidentiality. In 2001, Directive 2001/97/EC was adopted, which amended Council Directive 91/308/EEC of 10 June 1991 on Prevention of the Use of the Financial System for the Purpose of Money Laundering ${ }^{26}$ in such a way that it also included independent legal professions among the entities having an obligation to report suspicious financial transactions. In 2005, Directive 91/308/EC was replaced by Directive 2005/60/EC of the European Parliament and of the Council of 26 October 2005 on the Prevention of the Use of the Financial System for the Purpose of Money Laundering and Terrorist Financing ${ }^{27}$, while the transposition of this Directive

${ }^{26}$ Official Journal of the EC L 166, 28.06.1991.

27 Official Journal of the EU L 309, 25.11.2005. 
into the legal system of the Slovak Republic occurred (in relation to the profession of attorney) in $\S 23(1)$ of Act No. 586/2003 on the Legal Profession as amended and § 5(1)(j) of Act No. 297/2008 on Prevention of Legalization of the Proceeds of Criminal Activity and Terrorist Financing and on Amendments and Supplement to Certain Acts as amended. In this way, the duty of an attorney (or other obligated entities) to report suspicious financial transactions was introduced into the legal system of the Slovak Republic. This provision should ensure that the practice of a legal profession is not abused for the purposes of secrecy of money laundering operations or for the support of terrorist attacks, i.e. to eliminate active assistance of an attorney in committing criminal acts. According to recital 20 of the Preamble of Directive 2005/60/EC of the European Parliament and of the Council, the limit of this duty of an attorney is a situation, in which the attorney learns of a suspicious financial transaction before judicial proceeding, during judicial proceeding or in the course of ascertaining the legal position of a client ${ }^{28}$. This has been reiterated in recital 9 of the Preamble of the recently adopted Directive 2015/849 of the European Parliament and of the Council of 20 May 2015 on the Prevention of the Use of the Financial System for the Purposes of Money Laundering or Terrorist Financing, repealing Directive 2005/60/EC ${ }^{29}$. In other words, the limit given by the Western European concept of the rule

${ }^{28}$ Recital 20 of the Preamble of Directive 2005/60/EC:

"Where independent members of professions providing legal advice which are legally recognised and controlled, such as lawyers, are ascertaining the legal position of a client or representing a client in legal proceedings, it would not be appropriate under this Directive to put those legal professionals in respect of these activities under an obligation to report suspicions of money laundering or terrorist financing. There must be exemptions from any obligation to report information obtained either before, during or after judicial proceedings, or in the course of ascertaining the legal position for a client. Thus, legal advice shall remain subject to the obligation of professional secrecy unless the legal counsellor is taking part in money laundering or terrorist financing, the legal advice is provided for money laundering or terrorist financing purposes or the lawyer knows that the client is seeking legal advice for money laundering or terrorist financing purposes".

${ }^{29}$ Official Journal of the EU L 141, 5.6.2015. 
of law is the preservation of rights and of the duty of confidentiality in the practice of legal profession in cases when it concerns legal assistance which does not serve to plan a secret financial transaction in order to carry out money laundering or support terrorism, thus, in situations when the practice of legal profession serves as a control or counterbalance to the activity of public authorities in relation to a citizen (or a legal person).

With respect to this, it is important to note that the Court of Justice of the EU on 26 June 2007 in the preliminary ruling requested by the Constitutional Court of the Kingdom of Belgium in the case Ordre des barreaux francophones et germanophone and Others $v$ Consel des ministers, Case C-305/05, claimed that the duty of an attorney to inform and cooperate with authorities responsible for the fight against money laundering established by Directive 91/308/EEC (repealed by Directive 2005/60/EC) does not infringe the right to a fair trial as it is secured by Article 6 of the ECHR, because Article 6(3) of this Directive limits the duty of an attorney in cases when it concerns information received during the ascertainment of the legal position of a client or during performing the task of defending or representation of the client in or concerning a judicial proceeding, regardless of whether he obtained this information before, during or after such judicial proceedings. Such limit is also enshrined in Article 34(2) of the new Directive 2015/849/EC, which is currently in force: "Member States shall not apply the obligations laid down in Article 33(1) to notaries, other independent legal professional, auditors, external accountants and tax advisors only to the strict extent that such exemption relates to information that they receive from, or obtain on, one of their clients, in the course of ascertaining the legal position of their client, or performing their task of defending or representing that client in, or concerning, judicial proceedings, including providing advice on instituting or avoiding such proceedings, whether such information is received or obtained before, during or after such proceedings".

In relation to this, it is necessary to make a critical remark that this limitation of the duty to inform should apply to all administrative proceedings, or legal advice not directed at actively assisting in the commission of a criminal act. A similar view is taken by the 
Constitutional Court of the Kingdom of Belgium which has decided that all activities of attorneys, whether related to litigation or not, should benefit from the protection of the institution of attorneyclient privilege ${ }^{30}$.

In my own view, this requirement should be taken into account in the appropriate interpretation of Section 22(1) of Act No. 297/2008 Coll. on Prevention of Legalization of the Proceeds of Criminal Activity and Terrorist Financing and on Amendments and Supplement to Certain Acts as amended, which limits the duty of attorneys to inform about the activities of their clients and which states the following:

Section 22

Special Provisions relating to Advocates and Notaries

(1) The provisions of Section 17, subsections 1 and 5 and Section 21 shall not apply to an advocate if it concerns the information about the customer obtained from the customer or in any other way during or in connection with

a) processing legal analysis,

b) defending the customer in criminal law proceedings,

c) representing the customer in court proceedings or

d) providing legal advice related to the proceedings referred to at letters b) and c) including legal consulting on the commencement or prevention of the proceedings referred to at letters b) and c), regardless of whether such information was received or obtained prior to, during or after such proceedings.

The institution of confidentiality between attorneys and clients would, in this case, be legitimately protected, if the concept of "legal advice on [...] the prevention of the proceedings referred to at letters b) and c)" was interpreted as including any proceedings on minor offences or administrative offences.

${ }^{30}$ T. Spronken, J. Fermon, Protection of Attorney-Client Privilege in Europe, “Penn State International Law Review” 2008, No 2, p. 461. 


\section{Teleological interpretation of the attorney-client privilege*}

Legal norms need to be interpreted in the context of the purpose they are supposed to serve, that is to say, in the context of the objective to be achieved by their application. The same applies to legal professional privilege. Act No. 586/2003 Coll. on the Legal Profession ${ }^{31}$ states that advocacy helps to exercise the constitutional right of natural persons to defence and to protect other rights and interests of natural persons and legal persons. Likewise are defined the roles of advocacy in the academic literature: "Advocacy ensures the provision of legal services to natural persons and legal persons; it is mainly an assistance in exercising the constitutional right of citizens to defence and legal assistance and at the same time, also a protection of their other rights [... $]^{\prime 32}$. In the context of the roles of advocacy, it is also necessary to interpret the substance of the institution of the attorney-client privilege. The basis of the attorney-client privilege is the obligation of an attorney to keep confidential about all the facts that he has gained knowledge about while exercising the legal profession. Colloquially, the institution of the attorney-client privilege can be summarised in a quote from the poem by Miroslav Válek: “and they will ask you. But you tell them: I do not know. My memory is a mirror they breathed upon. I do not remember"33.

* This article is a result of the project "Impacts of law-making of the European Union on the law-making of a Member State of the European Union in terms of legislative technique and the law-making process" which is funded by the Scientific Grant Agency of the Ministry of Education, Science, Research and Sport of the Slovak Republic and of the Slovak Academy of Sciences (contract no. 1/0192/15).

${ }^{31}$ The long title of the act is Act No. 586/2003 Coll. on the Legal Profession and on Amending Act No. 455/1991 Coll. on the Business and Self-Employment Services (Business Licensing Act) as amended.

${ }^{32}$ K. Klíma et al., Encyklopedie ústavního práva, Prague 2007, p. 3.

33 The poem "Domov sú ruky, na ktorých smieš plakat" from the collection Prítažlivost' (1961). M. Válek, Básnické dielo, Bratislava 2005, p. 100. 
From a constitutional point of view, the application of the institution of attorney-client privilege has substantially more complicated connotations (it may concern the right of free exercise of a profession of an attorney and also the right to a fair trial). And a really thin ice is the application of exceptions to this rule. The application of an exception to the attorney-client privilege is precisely what I want to pursue in this article. It can be said that the breaches of the attorney-client privilege are always a very delicate matter. The institution of legal professional privilege is in a democratic society linked to the pursuit of legitimate democratic goals and to the institution of rule of law. The duty of confidentiality of an attorney establishing a relationship of trust between an attorney and a client can be regarded as a basic element and a basic condition for providing legal assistance ${ }^{34}$ and for ensuring justice ${ }^{35}$. The German theory states that the legal professional privilege serves two purposes. Firstly, it protects the individual interests of a client to ensure that the information that he entrusted to the attorney would not be given to third persons. Secondly, it should protect the general interest in the practice of legal profession ${ }^{36}$ as an indispensable condition for the functioning of the dispensation of justice. The professional

${ }^{34}$ The attorneys provide in particular special protection of so-called judicial rights. They help to apply the constitutional right of natural persons to defence and to protect other rights and interests of natural persons and legal persons by representing the clients before courts, public authorities and other legal entities; by providing the defence in criminal proceedings; by providing legal assistance and processing legal analysis etc. Already in Justinian's Corpus iuris civilis from 534, the role of an attorney is described as: "Attorneys who clarify [...] the problems of case and help the person concerned to restore the law are not less useful to the citizens than a soldier resistant to the wounds and battles who fights for the defence of his homeland and family. We think that not only those who are armed with sword are fighting for our empire, but also the attorneys who, with well elaborated words and arguments, are defending the hope, the life and the livelihood of their clients”. See R. Mgnus, Das Anwaltsprivileg und sein zivilprozessualer Schutz, Tübingen 2010, p. 10.

${ }^{35}$ L. Řehulová, op. cit., p. 397.

36 The exercise of legal profession in the Slovak Republic is regulated in Act No. 586/2003 Coll. on the Legal Profession and on Amending Act No. 455/1991 Coll. on the Business and Self-Employment Services (Business Licensing Act) as amended. 
privilege shall protect the general trust of the population in the attorney-client privilege which forms the basis for the exercise of legal profession. The status of legal professional privilege, as the basis for building a confidential relationship between the client and the attorney, is also confirmed by the jurisprudence of the $\mathrm{ECtHR}^{37}$ or by the national constitutional jurisprudence.

For instance, the Constitutional Court of the Czech Republic has also in several of its decisions stated that the duty of confidentiality is a basic condition for providing legal assistance and therefore, it is an indispensable condition for the functioning of a democratic society. This constitutional jurisprudence points to the fact that the exercise of the legal profession is based on the confidential relationship between an attorney and a client and on the trust of the client in the confidentiality of the attorney. In no way however, is this confidentiality a privilege of an attorney that could be used to exempt him from a generally valid and binding legal order. But it is an obligation imposed on the attorney in the interest of his clients and for their protection. In this respect, legal professional privilege enjoys adequate protection ${ }^{38}$.

\section{Attorney-client privilege and the right to a fair trial}

Generally speaking, from the client's point of view, the attorneyclient privilege is part of the constitutional right to a fair trial ${ }^{39}$. The definition of the right to a fair trial begins already in Article 46 of the Constitution of the Slovak Republic (Constitution of the SR) with the requirement for impartiality and independence of court. The concretisation of other elements of the right to a fair trial in

37 See for example the decision of the European Court of Human Rights in the case André and Another v France, App. No. 18603/03, point 41.

38 See for example the Judgement of the Constitutional Court of the Czech Republic II. ÚS 2894/08 from 28 August 2009, p. 8, or the Judgement II. ÚS 889/10 from 25 November 2010, point 17.

39 For example, J. Drgonec, Ústava Slovenskej republiky: teória a prax, Bratislava 2015, p. 836 and following. 
Articles 47 and 48 of the Constitution of the SR can be understood as the principles of the exercise of judiciary or judicial rights applicable to the general judiciary (including criminal judiciary) and to a large extent also to other legal protection exercised mostly by the public administration authorities but also by attorneys. Part of the right to a fair trial is also the right to refuse to give testimony (so called prohibition of self-incrimination). And since the attorney shall be perceived as an alter ego of his client, the duty of confidentiality of an attorney may be subsumed under the prohibition of self-incrimination and thus under the already mentioned constitutional right to a fair trial.

The institution of attorney-client privilege enjoys protection and respect also in supranational norms even though it may not be explicitly mentioned. For example, the $\mathrm{ECHR}^{40}$ does not explicitly mention the attorney-client privilege, but since the relatively simple text of the ECHR is constantly developed by Strasbourg's enormously rich jurisprudence, the protection of this institution can also be based in the above-mentioned Convention. The ECtHR in Strasbourg founds its decisions related to the institution of the attorney-client privilege on Article 6 of the ECHR (right to a fair trial) and Article 8 of the ECHR (right to respect for private and family life). The majority of cases is decided based on Article 8 of the ECHR, so in the context of the protection of privacy ${ }^{41}$. But in the case Niemietz $v$ Germany, App. No. $13710 / 88^{42}$, in its decision from 16 December 1992 that represented a milestone for the institution of professional privilege, the ECtHR pointed to the fact that when it comes to an attorney, the unauthorised impingement on the professional privilege may have repercussions on the proper dispensation of justice and therefore on the rights guaranteed by Article 6 of the $\mathrm{ECHR}^{43}$.

40 Published in the Collection of Laws of the Slovak Republic under No. 209/1992 Coll.

${ }^{41}$ T. Spronken, J. Fermon, op. cit., p. 461.

42 Decision of the European Court of Human Rights in the case of Niemietz $v$ Germany, App. No. 13710/88, para 37.

${ }^{43}$ T. Spronken, J. Fermon, op. cit., p. 444-445. 


\section{Breaches of the attorney-client privilege}

An interference with the attorney-client privilege is caused by the activities of public authorities. Therefore, it can be stated that the standard requirements that have to be generally respected in the activities of public authorities also apply to the interference with the attorney-client privilege. The breach of privacy protection, including the breach of the duty of confidentiality can be caused by the public authorities only exceptionally, based on law and only if it is necessary and the purpose pursued by the public interest cannot be achieved otherwise. If any of the above mentioned conditions was not met, the intervention would be unconstitutional. Also important is the teleological aspect of the breaches of the attorney-client privilege. If the constitutional order allows the breach of this protection it is only in the interest of protection of a democratic society and only when this breach is absolutely necessary. Considered as necessary may be the general interest of protection of the public from criminal acts as well as the detection and punishment of these acts. The prosecution of criminal acts and the fair punishment of perpetrators is a constitutionally approved public interest, the essence of which is the transfer of responsibility for the punishment of the most serious violations of fundamental rights and freedoms committed by natural persons and legal persons to the state. As the Constitutional Court of the Czech Republic has judged, the aim of the law establishing the institution of attorney-client privilege is not only to protect the duty of confidentiality of the attorney but also to prevent perpetrators of criminal activity from misusing the attorney-client privilege by knowingly committing criminal activity with his knowledge and using his office as a cover, believing that it provides them with sufficient protection from the law enforcement authorities ${ }^{44}$. On

44 Judgment of the Constitutional Court of the Czech Republic from 24 March 2014 with number: III. ÚS 3988/13. 
the other hand, the limits of necessity must not be exceeded and the interference of the public authorities must be proportionate. If criminal law allows the state to realize a public interest in prosecuting criminal activity through robust and individual personal integrity limiting instruments, then the use of such instruments must respect certain constitutional limits since the use of these instruments is connected with a serious limitation of fundamental rights and freedoms of an individual. The ideal of criminal law formulating the boundary between the criminal power of the state and the freedom of an individual consists in the exercise of the state's criminal power not being an instrument of an arbitrariness of temporary holders of the state power against the individual ${ }^{45}$.

Theses allowing, under certain conditions, the breach of the attorney-client privilege have support also in the international doctrine. For instance, the jurisprudence of the ECtHR also confirms that the protection of contact between an attorney and his client is not absolute or untouchable and under certain circumstances it can be limited ${ }^{46}$.

When are then the breaches of the attorney-client privilege legitimate and constitutionally conformable? In general, it can be stated that the misuse of law should not benefit from legal protection. The plausible thesis is therefore that the possible commission of criminal activity by an attorney either damaging his client or other persons in cooperation with his client cannot be considered as providing legal services and for that reason it cannot profit from any protection ${ }^{47}$. As a very illustrative example of the attempted misuse of the institution of attorney-client privilege could be the case of the Constitutional Court of the Czech Republic with which it dealt in its finding III. ÚS 2847/14.

\footnotetext{
45 J. Kallab, Zločin a trest, Úvahy o základech trestního práva, Prague 1916, p. 8.

${ }^{46}$ Decision of the ECtHR from 6th December 2012 in the case Michaud v France, App. No. 12323/11, paragraph 123.

${ }^{47}$ Decision of the Constitutional Court of the Czech Republic from 12 November 2014, with number: I. ÚS 1638/14.
} 


\section{The Constitutional Court of the Czech Republic - Finding III. ÚS 2847/14}

On 3 January 2017, the Constitutional Court of the Czech Republic decided in its finding III. ÚS $2847 / 14$ to reject the constitutional complaint of the attorney - complainant, who claimed the unconstitutionality of the spatial wiretapping of the conversations between him as an attorney and his client who had agreed with the wiretapping and basically had initiated it.

The complainant, as an attorney, received from his client a sum of $550.000 \mathrm{CZK}$ that he was supposed to use, according to their mutual agreement, to secure and influence the witnesses in criminal proceedings with a purpose of reopening the criminal proceedings in which the client was convicted and served his imprisonment sentence. During his visits in the prison, the attorney let his client believe that he had successfully arranged the reopening of the criminal proceedings, but in reality, he did not use the money for this purpose and kept them for his own use. The client has initiated a criminal prosecution against his attorney and the recordings from the wiretapping of their conversations that took place during the visits in prison should have served as evidence against the attorney. The attorney was consequently convicted of fraud. The attorney/defender has challenged the sentence with a constitutional complaint arguing that legal provisions concerning the confidentiality and inviolability of the communication between the attorney and the client include not only the duty of confidentiality of the attorney but also the right of the attorney to talk to the client without the presence of the third persons. According to the attorney/complainant, by recording such conversations, the interests of his clients who did not give the permission for the wiretapping were threatened. Based on this, the complainant deduced that the absolute protection from wiretapping does not concern only the information that the client gives to his attorney but also the communication from the attorney towards his client. 
The complainant - attorney was therefore claiming throughout the process the impermissibility of the fabrication and the use of the recordings from the prison premises, on which he was consulting his client. He used this procedure of the law enforcement authorities as the main argument of his objections in the constitutional complaint. He also referred to the provisions of $\S 158(d)$ section 1 of the Criminal Procedure Code of the Czech Republic, Article 3 of Act No. 169/1999 Coll. on the Imprisonment or § 16(c) of Act No. 555/1992 Coll. on the Prison Service and the Judiciary Guards of the Czech Republic. According to these legal provisions, the attorney has among other things "the right, within his authority, to correspond and talk to his client without the presence of a third person" and the operative-search means "must not be used during the contact between the person serving the prison sentence and his attorney". "If a Police authority ascertains that the accused person is communicating with his defence counsel, it is obliged to destroy the record containing this communication and not to use facts learned in this connection in any way".

The Constitutional Court of the Czech Republic did not identify itself with the argumentation of the complainant. On the contrary, it pointed out that the interpretation and application of the provisions protecting the attorney-client privilege has to be done restrictively (exceptiones non sunt extendendae) and in conformity with their purpose that legitimises these provisions with respect to the need of the effective guarantees of the constitutional right of defence. Cited provisions protecting the legal professional privilege are a concretisation of the constitutional right of defence, or potentially, of the right to legal assistance of which the essential part is also the right of each individual to consult his attorney under the condition that he is not providing any information to the law enforcement authorities at the same time. In such a case, the communication between the attorney and his client is subject to the maximal possible protection and this is in the interest of the client. This guides the interpretation of the meaning of these provisions. Their purpose is to protect the interests of the client, possibly to respect the principle of "equality of arms" in criminal proceedings. However, according to the Constitutional Court of 
the Czech Republic, these provisions do not provide protection to a communication for a benefit of an attorney whose interests are in contradiction with the interests of his client or are not related to the interests of the client.

According to the jurisprudence of the Constitutional Court of the Czech Republic (for instance, its decision from 12 October 2014 with number I. ÚS 1638/14) the critical criteria to determine whether the communication is protected or not are the eligibility of providing legal services and the interests of the client. Their fulfilment represents the material conditions for the constitutionality of the limitations of the fundamental rights and freedoms of the attorney in the form of wiretappings. The protection of the attorney is in these cases a reflection of the right of defence and the right to legal assistance. The holder of these rights is, however, the person against whom a prosecution is brought and whose procedural rights might be in such proceedings seriously violated. On the contrary, the attorney acts as a holder of the right to privacy and its individual aspects as any natural person and also as a holder of the right to freely practice a profession while the practice of this profession is a guarantee of the right of defence. All the extraordinary protection of the activity of an attorney leads exclusively to the protection of the clients and to insuring their constitutional right of defence and to legal assistance. The holder of such a fundamental right is therefore a client and not an attorney. The attorney in this case does not exercise his rights, but on the contrary, he carries out the important obligations of his profession given by the law. In case in which a client knowingly gives up this protection, in particular in the situation in which he claims the help from the state power against the attorney who did not protect his interest in a proper way, insisting on such a protection would be a constitutionally unconformable interpretation of the provisions protecting the attorney-client privilege.

Likewise, in the case Versini-Campinchi and Crasnianskiv France, App. No. 49176/11, the ECtHR ruled that attorney-client privilege does not preclude the transcription of exchanges that contain evidence that the attorney participated in a crime, as long as the exchanges are not used against the attorney's client. 


\section{Conclusion}

For the effective performance of certain professions, it is condicio sine qua non to have an access to sensitive information from the client. The client would not disclose this information, if he/she was not aware they were indispensable for the expert - professional, whom he/she asked for help and which the expert would not reveal to another person. I am talking about the professional privilege that must be kept by a doctor, a priest, a notary or by an attorney. In the context of the attorney-client privilege, it should be stressed that the interpretation and application of legal standards cannot be carried out completely autonomously that is, without regard to the protection of fundamental rights of individuals ensuing from the constitutional framework. Nor can the fundamental rights of an individual be interpreted autonomously, but only in correlation with the rights of other individuals. Although the institution of attorney-client privilege may be perceived as a condicio sine qua non for the implementation of the constitutional right of free exercise of the profession of an attorney, since without this institution, the effective exercise of the profession of an attorney is not possible, but the rationale for the normative establishment of the institution in the legal order is mainly the effective realization of the right to a fair trial for the attorney's client. Therefore, it can not be perceived as a privilege of a lawyer, but rather as a right of the client and, its essence and exceptions must be interpreted in this context. The the attorney-client privilege is therefore not absolute. Even the ECtHR recognizes that sometimes the privilege of attorney-client relationship is less important than, for example, the fight against terrorism or money laundering. And in no case can the institution of attorney-client privilege serve as a guarantee for committing crimes. Therefore, it is important to appreciate the pragmatic and moderate approach of the Constitutional Court of the Czech Republic, which was demonstrated in the case III. ÚS 2847/14.

In my opinion, it is legitimate that the attorney-client privilege is not absolute in order to prevent criminal activities of attorneys under the guise of asset management. However, this institution 
needs to be protected as part of power balancing of the relationship between the individual and the state, ergo as part of service of justice. Just at the time of taking stand on the contradictory nature of a criminal proceeding, it is easy to say that the prosecutor, the investigator and the related state machinery are pulling one end of the rope and on the other hand, stands a citizen who should be assisted by an attorney, so the state does not exploit its power. The right of defense, which is also protected by the attorney-client privilege, is the right of a client and not the other way around and it is crucial to look at it in this particular context. At the same time, however, insensitive breaches of the institution of attorney-client privilege may constitute gross violations of constitutional rights, such as the rights of defence, the right to protection of private life, or the right of free exercise of a profession.

\section{STRESZCZENIE}

\section{Obowiązek zachowania tajemnicy adwokackiej}

(historia i cel)

Podstawą tajemnicy zawodowej prawnika jest obowiązek zachowania poufności wszystkich faktów, o których prawnik dowiedział się w związku z wykonywaniem swojego zawodu. Treść ustanowienia obowiązku zachowania przez prawnika tajemnicy zawodowej należy interpretować w odniesieniu do celu, któremu powinna służyć. Zasada objęcia prawnika obowiązkiem zachowania tajemnicy zawodowej nie ma charakteru absolutnego. $Z$ jednej strony, obowiązek poufności gwarantuje zaufanie w relacji klient-prawnik. Ponadto, umożliwia ochronę konstytucyjnych praw klienta wynikających z prawa do rzetelnego procesu sądowego lub wymogów praworządności. $Z$ tego powodu obowiązek ten nie powinien być postrzegany jako przywilej adwokata ( $\mathrm{z}$ ang. attorney-client privilege) lecz raczej jako prawo przysługujące klientowi. Co więcej, ustanowienie obowiązku zachowania tajemnicy akdwokackiej w żadnym wypadku nie może stanowić środka ochronnego w sytuacji, gdy dochodzi do popełnienia czynu zakazanego. Jednocześnie jednak naruszenie tajemnicy adwokackiej może być poważnym naruszeniem praw konstytucyjnych, takich jak prawo do obrony procesowej, ochrony życia prywatnego lub swobodnego wykonywania zawodu. Orzecznictwo Europejskiego Trybunału Praw Człowieka, podobnie jak 
orzecznictwo Trybunału Konstytucyjnego Republiki Czeskiej potwierdzają zasadność powyższych postulatów.

Słowa kluczowe: tajemnica zawodowa; adwokat; prawo do rzetelnego procesu sądowego; cel normy prawnej; ochrona praw klienta; nadużycie prawa

\title{
SUMMARY
}

\author{
Attorney-client privilege \\ (History and aim - constitutional view)
}

The basis of the attorney-client privilege is the duty of a lawyer to maintain the confidentiality of all facts about which he has learned in relation to the exercise of the legal profession. The content of the institution of attorney-client privilege must be interpreted in light of the purpose it should serve. The principle of attorney-client privilege is not absolute. On the one hand, the duty of attorney's confidentiality is a guarantee of a confidential relation between the client and the attorney. It enables attorneys to provide the protection of the client's constitutional rights stemming from the right to a fair trial or requirements of the rule of law. Therefore, it cannot be perceived as the privilege of an attorney, but more as the right of the client. Moreover, in no case shall the institution of confidentiality serve as a protective unit for committing criminal acts. At the same time, however, insensitive breaches of the institution of attorney-client privilege may constitute gross violations of constitutional rights, such as the rights of defence, the right to protection of private life, or right of free exercise of a profession. The case law of the European Court of Human Rights, as well as, the case law of the Constitutional Court of the Czech Republic confirm the mentioned postulates.

Keywords: professional privilege; attorney; right to a fair trial; purpose of a legal standard; protection of clients' rights; abuse of rights

\section{BIBLIOGRAPHY}

Drgonec J., Ústava Slovenskej republiky: teória a prax, Bratislava 2015.

Fábry B., Kasinec, R., Turčan, M., Teória práva, Bratislava 2017.

Gerloch A., Teorie práva, Plzeň, 2007.

Gřivna T. et al., Právo na obhajobu, Teorie a praxe 21. století, Plzeñ 2017. 
Chylo J., Löwy J., K limitom mlčanlivosti advokáta, “Justičná revue” 2016, No 10.

Kallab J., Zločin a trest, Úvahy o základech trestního práva, Prague 1916.

Klíma K., Ústavní právo, Fifth ed., Plzeñ 2017.

Klíma K. et al., Encyklopedie ústavního práva, Prague 2007.

Kmec J. et al., Evropská úmluva o lidských právech, Prague 2012.

Magnus R., Das Anwaltsprivileg und sein zivilprozessualer Schutz: eine rechtsvergleichende Analyse des deutschen, französischen und englischen Rechts, Tübingen 2010.

Pejchalová V., Hájíčková, K., Problematika domovnich prohlidek advokátních kanceláří ve světle evropské judikatury, "Bulletin Advokacie” 2014, No 4.

Řehulová L., Institut zproštění povinnosti mlčenlivosti advokáta klientem, "Právní rozhledy" 2011, No 11.

Spronken T., Fermon J., Protection of Attorney-Client Privilege in Europe, "Penn State International Law Review" 2008, No 2.

Válek M., Básnické dielo, Bratislava: Kalligram, Ústav slovenskej literatúry SAV, Bratislava 2005.

Záhora J. (ed.), Teoretické a praktické problémy využivania informačnotechnických prostriedkov v trestnom konani, Prague 2017. 